\title{
Selection strategies of segregant soybean populations for resistance to Asian rust
}

\author{
Aliny Simony Ribeiro(1), José Francisco Ferraz de Toledo(2) and Magno Antonio Patto Ramalho(1) \\ (1)Universidade Federal de Lavras, Departamento de Biologia, Caixa Postal 3037, CEP 37200-000 Lavras, MG, Brazil. E-mail: aliny@cnpso.embrapa.br; \\ magnoapr@ufla.br (2)Embrapa Soja, Caixa Postal 231, CEP 86001-970 Londrina, PR, Brazil. E-mail: toledo@cnpso.embrapa.br
}

\begin{abstract}
The objective of this work was to identify the best selection strategies for the more promising parental combinations to obtain lines with good resistance to soybean Asian rust (Phakopsora pachyrhizi). Two experiments were carried out in the field during the 2006/2007 and 2007/2008 growing seasons, to determine the percentage of infected leaf area of individual plants of five parents and their segregant $F_{2}$ and $F_{3}$ populations. The data obtained indicates that additive genetic variance predominates in the control of soybean resistance to Asian rust, and that the year and time of assessment do not significantly influence the estimates of the genetic parameters obtained. The narrow-sense heritability $\left(\mathrm{h}_{\mathrm{r}}^{2}\right)$ ranged from 23.12 to $55.83 \%$, and indicates the possibility of successful selection of resistant individuals in the early generations of the breeding program. All the procedures used to select the most promising populations to generate superior inbred lines for resistance to P. pachyrhizi presented similar results and identified the BR01-18437 x BRS 232 population as the best for inbred line selection.
\end{abstract}

Index terms: Glycine max, Phakopsora pachyrhizi, additive variance, heritability, selection.

\section{Estratégias de seleção de populações segregantes de soja para resistência à ferrugem-asiática}

\begin{abstract}
Resumo - O objetivo deste estudo foi identificar as estratégias mais eficientes para selecionar as combinações parentais mais promissoras e obter linhas com bom grau de resistência à ferrugem-asiática da soja (Phakopsora pachyrhizi). Dois experimentos foram realizados em campo nos anos agrícolas 2006/2007 e 2007/2008, para avaliar a percentagem da área foliar infectada em plantas individuais de cinco parentais e das suas populações segregantes $\mathrm{F}_{2}$ e $\mathrm{F}_{3}$. Os dados obtidos indicam que a variância genética aditiva predomina no controle da resistência da soja à ferrugem-asiática e que os anos e as épocas de avaliação não influenciaram significativamente as estimativas dos parâmetros genéticos obtidos. A herdabilidade no sentido restrito $\left(\mathrm{h}_{\mathrm{r}}^{2}\right)$ variou de 23,12 a 55,83\%, o que indica a possibilidade de sucesso com a seleção de indivíduos resistentes em gerações precoces nos programas de melhoramento. Todos os procedimentos usados para selecionar as populações mais promissoras na geração de linhagens superiores quanto à resistência a $P$. pachyrhizi apresentaram resultados similares e identificaram a população BR01-18437 x BRS 232 como a melhor para a seleção de linhagens.
\end{abstract}

Termos para indexação: Glycine max, Phakopsora pachyrhizi, variância aditiva, herdabilidade, seleção.

\section{Introduction}

Soybean Asian rust, caused by the Phakopsora pachyrhizi Syd. \& P. Syd. fungus, has a high potential for crop damage by causing fast leaf yellowing and premature fall, preventing full pod filling. Since 2001, epidemics of the disease have been reported in practically all Brazilian soybean cropping areas. The regions where the disease has been most aggressive vary from harvest to harvest due to changes in climatic conditions, with development of the pathogen favored by a temperature range of $15-29^{\circ} \mathrm{C}$ and by high humidity (Garcia et al., 2008).

The main control method for the disease has been the use of chemical products (Godoy \& Henning, 2008), which significantly increase production costs. Therefore, attention has been directed to obtaining resistant genotypes. When developing a breeding program for rust resistance, information on the genetic control of soybean resistance is essential, and some Brazilian reports are already available in the literature (Pierozzi, 2007; Ribeiro et al., 2007). This information

Pesq. agropec. bras., Brasília, v.44, n.11, p.1452-1459, nov. 2009 
concentrates results on genetic mean and variance, but whether these estimates vary with the time of assessment of disease severity and between years should also be checked.

One of the breeder's most important decisions is identifying, amongst the many segregant populations obtained, the few with the greatest chance of originating superior lines, to concentrate his attention on these populations. This decision should be taken in the earliest possible generations. There are several methods used for the selection of very promising populations. Among them, it is important to highlight diallel analysis, which has already been used to select genotypes resistant to Asian soybean rust, identifying the BR01-18437 line with high combining ability (Ribeiro et al., 2009). However, Baenziger \& Peterson (1991) also showed interesting alternative assessment methods, which have not been used for selecting populations for resistance to Phakopsora pachyrhizi yet.

The objective of this work was to determine which strategies are more efficient in selecting the most promising parental combinations to obtain lines with a good level of resistance to soybean Asian rust (Phakopsora pachyrhizi).

\section{Materials and Methods}

The trials were carried out at Embrapa Soja's experimental station in Londrina, Paraná $\left(23^{\circ} 23^{\prime} \mathrm{S}\right)$, in a Latossolo Vermelho eutroférrico (Rhodic Eutrudox). The region has warm and wet subtropical climate with annual temperatures ranging from 11 to $29^{\circ} \mathrm{C}$.

The soybean inbred lines/cultivars BR01-18437, BRS 184, BRS 231, BRS 232 and Embrapa 48 were obtained from the active genebank at Embrapa Soja. The lines were chosen according to prior studies, which had shown different responses to soybean Asian rust (Ribeiro et al., 2007, 2008; Pierozzi et al., 2008). The parental materials for the experiments were derived from the referred inbred lines/commercial cultivars by random selection followed by multiplication of a single plant from each cultivar. The parents were crossed in December 2004, using a complete diallel cross scheme, without reciprocals, under greenhouse conditions, and the $F_{1}$ seeds of ten populations were obtained. The $F_{1}$ and $F_{2}$ generations and the parents were multiplied in a greenhouse during the fall/winter of 2005 and 2006.
During the 2006/2007 and 2007/2008 growing seasons, the parents and the $F_{2}$ and $F_{3}$ generations of the ten populations were assessed under field conditions using a completely randomized design. Hill plots, each with a single plant, were used. The treatments consisted of the five parents, ten $F_{2}$ populations and ten $\mathrm{F}_{3}$ populations, totaling 25 treatments. The number of replicates was 50 plants per parent, 160 plants per $\mathrm{F}_{2}$ population and 200 plants per $\mathrm{F}_{3}$ population.

In both seasons, the spacing was of $1.5 \mathrm{~m}$ between rows and $0.20 \mathrm{~m}$ between plots within rows. Two border rows of remnant seeds from the experiment were sown between each useful row, resulting in a final experimental set spacing of $0.5 \mathrm{~m}$ between rows. Thus, the population density was of approximately 250,000 plants $\mathrm{ha}^{-1}$, providing a homogeneous level of competition for plants of the study plots.

The experimental treatments, including fertilization and weed and insect control, were those recommended for soybean (Tecnologias de produção de soja, 2006) and included supplementary irrigation. Frequent hoeing and insecticide application when in the presence of pests was done to allow normal plant growth and development. Weekly supplementary irrigation was applied to ensure pathogen reproduction (Del Ponte et al., 2006).

Inoculation was carried out on the border rows, using a Mato Grosso state (MT) isolate, which was kept in a greenhouse on soybean filter plants of the BRS Bacuri cultivar. The inoculum origin, maintenance, preparation and inoculation were those described by Ribeiro et al. (2008) and Pierozzi et al. (2008).

The assessed trait was disease severity obtained as the percentage of leaf area infected by the pathogen. The first of two assessments was carried out 30 days after the first lesions were observed in the study plots (30 days after detection, DAD), when the plants had generally already started flowering. The second was carried out seven days later (37 DAD), using the scale proposed by Canteri \& Godoy (2003), which considers the percentage of host plant tissue affected. The two assessments were made on the eleventh trifoliate leaf of each plant. Therefore, the advance of the disease could be followed on the same leaf.

The genetic analyses were obtained with the MapGen program (Daniel Ferreira Furtado, Universidade Federal de Lavras, MG, 1993 - unpublished program), using three different models. The first was the

Pesq. agropec. bras., Brasília, v.44, n.11, p.1452-1459, nov. 2009 
complete model, which consisted of the additive $\left(\sigma_{\mathrm{A}}^{2}\right)$, dominance $\left(\sigma_{\mathrm{D}}^{2}\right)$ and environment $\left(\sigma_{\mathrm{E}}^{2}\right)$ variances of each assessment and each year of experimentation, for a total of 12 parameters. The second model involved three parameters, using data averaged over assessments and years and, therefore, the effects of year and time of assessment were not estimated. The last model was formed only by the $\sigma_{\mathrm{A}}^{2} \mathrm{e} \sigma_{\mathrm{D}}^{2}$ components.

Four procedures were carried out to obtain the estimates of the most promising lines. In the first, the heritability of the $\mathrm{F}_{3}$ individuals was obtained using the expression $h_{\mathrm{rF}_{3}}^{2}=1.5 \sigma_{\mathrm{A}}^{2} / \sigma_{\mathrm{F}}^{2}$, where $h_{\mathrm{rF}_{3}}^{2}$ is the narrow-sense heritability at the $\mathrm{F}_{3}$ level, $\sigma_{\mathrm{A}}^{2}$ is the additive variance, and $\sigma_{\mathrm{F}}^{2}$ is the phenotypic variance. The heritability error was obtained by an expression similar to that of Vello \& Vencovsky (1974): $\mathrm{V}\left(\mathrm{h}_{\mathrm{m}}^{2}\right)=\left[\left(\sigma_{\mathrm{F}}^{2}\right)^{2}\left(\hat{\mathrm{V}}\left(\sigma_{\mathrm{A}}^{2}\right)\right)\right]+\left[\left(\sigma_{\mathrm{A}}^{2}\right)^{2}\left(\hat{\mathrm{V}}\left(\sigma_{\mathrm{F}}^{2}\right)\right)\right]$, where the error of variance is obtained by the expression: $\hat{\mathrm{V}}\left(\sigma_{\mathrm{x}}^{2}\right)=2\left[\left(\sigma_{\mathrm{x}}^{2}\right)\right]^{2} /(\mathrm{DF}+2)$, where DF is the degree of freedom.

The second procedure consisted of the means of the lines in the $\mathrm{F}_{\infty}$ generation, that were estimated by $\mathrm{F}_{\infty}=\mathrm{m}+\mathrm{a}^{\prime}=2 \overline{\mathrm{F}}_{3}-\overline{\mathrm{F}}_{2}$, where $\mathrm{m}+\mathrm{a}^{\prime}$ is the contribution of the loci in homozygosis, that is, it estimates the contribution of the loci that are fixed in the two parent lines. Considering a single locus $\mathrm{m}$ is the midpoint between the two contrasting homozygotes and a' is the deviation of the homozygote in relation to the midpoint, $\bar{F}_{2}$ is the mean of the $F_{2}$ generation and $\bar{F}_{3}$ is the mean of the $\mathrm{F}_{3}$ generation (Oliveira et al., 1996).

The third procedure estimated the genetic potential of each population to generate superior (resistant and/or tolerant) inbred lines (Jinks \& Pooni, 1976), obtained by the expression $Z=\left(T_{1}-T_{2}\right) /\left(\sqrt{2 \sigma_{A}^{2}-\sigma_{E}^{2}}\right)$, where: $T_{1}$ is the mean minus the standard deviation of the parents with the least disease severity; $\mathrm{T}_{2}$ is $\mathrm{m}+\mathrm{a}$, which have been discussed previously. For $\mathrm{T}_{1}$, the subtraction of one standard deviation was used because populations with lowest disease severity of the best parentals were wanted.

The last procedure used for line selection was based on the estimates of the expected phenotypic means of the lines selected in the $F_{\infty}$ generation proposed by Bernardo (2002) using the expression $\mu_{\mathrm{F}}=\left(\mathrm{m}+\mathrm{a}^{\prime}\right)+\mathrm{k}_{\mathrm{P}}\left(2 \sigma_{\mathrm{A}}^{2} / \sqrt{2 \sigma_{\mathrm{A}}^{2}+\sigma_{\mathrm{E}}^{2}}\right)$, where $\mathrm{k}_{\mathrm{p}}$ is the standardized selection differential, and $\mathrm{p}$ is the proportion of individuals selected $-10 \%$ in this case. The other parameters were as previously discussed.

\section{Results and Discussion}

Table 1 shows the estimates of means and variances and the degrees of freedom of the parents and their derived segregant $F_{2}$ and $F_{3}$ generations, used to obtain the genetic parameters of variance for soybean Asian rust severity in the assessments made 30 and 37 days after detecting the disease, during the 2006/2007 and 2007/2008 growing seasons.

The capacity of soybean lines to express resistance to the pathogen can vary over time (Ribeiro et al., 2007). This seems to indicate that the genetic resistance mechanisms depend on environmental and physiological factors to begin to manifest in some inbred lines. Environmental conditions are important for pathogen development, and the disease occurs with greater severity in prolonged leaf wetting period and temperatures of 15 to $29^{\circ} \mathrm{C}$ (Garcia et al., 2008). This was confirmed in the severity assessment, with the greatest magnitudes of variance among parents, showing greater instability in the environmental effect on the manifestation of the disease. However, the variances are not appropriate to compare the variability of the data sets from each parent, and the use of the genetic variation coefficient seems more appropriate to express the variability of the data, as it is interpreted as the variability of the data average. In this case, the coefficients of genetic variation found for segregant populations ranging from 8.64 to $15.84 \%$ showed that the populations with lower levels of severity of the pathogen are those with more genetic variation, thus showing high variability or instability of the data. This instability in rust severity shown by some soybean lines has been reported on other occasions (Pierozzi, 2007).

The BR01-18437 line presented the lowest disease severity and was significantly different from other parents (Table 1). This line carries a recessive allele that confers RB-type resistance to lesions caused by the pathogen. But this type of resistance does not prevent the appearance of lesions, it only decreases their severity (Koga et al., 2008). RB-type lesions are actually hyper-sensitivity reactions that reduce the pathogen multiplication and disease incidence by 


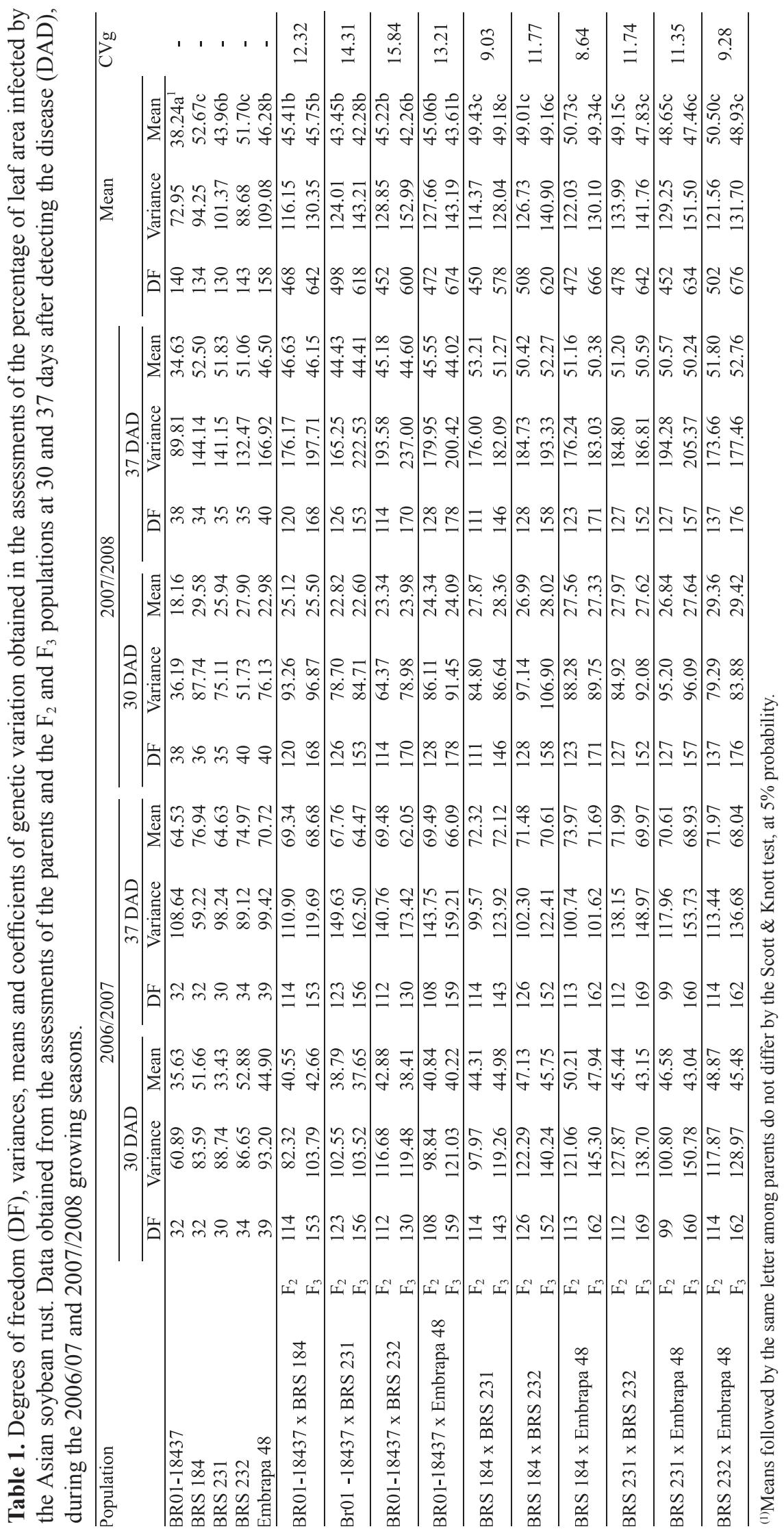


reducing the number of uredia and spore production (Pierozzi et al., 2008).

The percentage means of the leaf area infected by the pathogen in the $\mathrm{F}_{2}$ and $\mathrm{F}_{3}$ populations, considering each combination, were fairly similar (Table 1), showing primarily that the genetic control of the trait is little influenced by loci displaying dominance. Ribeiro et al. (2009), in fact, observed that additive effects predominated in the genetic control of soybean resistance to Asian rust. The segregant $F_{2}$ and $\mathrm{F}_{3}$ populations derived from crosses involving the BR01-18437 line showed lower disease severity and were significantly different from other populations.

It was observed that the phenotypic variance of the $\mathrm{F}_{2}$ and $\mathrm{F}_{3}$ generations was, as expected, higher than that of the parents, and the variance of the $F_{3}$ generation was higher than that of the $\mathrm{F}_{2}$ generation. The variance of the $F_{3}$ generation contains $3 / 2 \sigma_{A}^{2}+3 / 4 \sigma_{D}^{2}+\sigma_{E}^{2}$, while the $F_{2}$ generation contains $\sigma_{\mathrm{A}}^{2}+\sigma_{\mathrm{D}}^{2}+\sigma_{\mathrm{E}}^{2}$ (Souza Junior, 1989). Therefore, in the absence or presence of small dominance effects, the variance of the $\mathrm{F}_{3}$ generation was expected to be higher than that of the $\mathrm{F}_{2}$ generation, while the error is equal for both generations.

Table 2 shows the estimates of the components of the genetic and environmental variance. It is emphasized that only a few models were tested. The most complete model considered the estimate of $\sigma_{A}^{2}$, $\sigma_{\mathrm{D}}^{2}$ and $\sigma_{\mathrm{E}}^{2}$ for each year and time of assessment, that is, the model involved 12 parameters. Other models, not considering the effect of year and time of assessment, were then tested. As these last two models explained most of the variation (similar $\mathrm{R}^{2}$ estimates to the more parameterized ones), they were chosen to represent the genetic effects of soybean resistance to rust. With the evidence available that the effect of dominance is not important in the expression of resistance (means of the $\mathrm{F}_{2}$ and $\mathrm{F}_{3}$ generations similar to each other and with the means of the parents), the model without dominance variance was considered (Table 2 ). The $\mathrm{R}^{2}$ estimates in the model with and without dominance were very similar, provided dominance was not playing an important role in rust resistance.

However, since the dominance variance $\left(\sigma_{\mathrm{D}}^{2}\right)$ was estimated as deviation from the linear regression equation used to obtain $\sigma_{\mathrm{A}}^{2}$, the least-squares procedure would minimize $\sigma_{\mathrm{D}}^{2}$ when minimizing the deviations from the regression, since by definition it converges to the smallest possible deviation within the genotype values. Thus, a priori $\sigma_{A}^{2}$ would always be greater than

Table 2. Estimates of the components of genetic and environmental variance, with the respective lower and upper limits and determination coefficient of the percentage of the leaf area infected by Asian soybean rust. Data obtained from the assessments of the parents and the F2 and F3 populations at 30 and 37 days after detecting the disease, during the 2006/07 and $2007 / 2008$ growing seasons ${ }^{(1)}$.

\begin{tabular}{|c|c|c|c|c|c|c|c|c|c|c|}
\hline \multirow[t]{2}{*}{ Populations } & \multirow[t]{2}{*}{$\sigma_{\mathrm{A}}^{2}$} & \multicolumn{2}{|c|}{ Limits } & \multirow[t]{2}{*}{$\sigma_{\mathrm{D}}^{2}$} & \multicolumn{2}{|c|}{ Limits } & \multirow[t]{2}{*}{$\sigma_{\mathrm{E}}^{2}$} & \multicolumn{2}{|c|}{ Limits } & \multirow[t]{2}{*}{$\mathrm{R}^{2}$} \\
\hline & & Lower & Upper & & Lower & Upper & & Lower & Upper & \\
\hline \multirow{2}{*}{ BR01-18437 x BRS 184} & 29.85 & 27.57 & 32.41 & 2.91 & 2.66 & 3.19 & 83.39 & 71.01 & 99.32 & $0.90^{*}$ \\
\hline & 31.52 & 28.43 & 35.14 & - & - & - & 83.66 & 71.94 & 98.52 & $0.90 *$ \\
\hline \multirow{2}{*}{ BR01-18437 x BRS 231} & 38.06 & 35.11 & 41.39 & -0.72 & -0.66 & -0.79 & 86.67 & 73.73 & 103.38 & $0.90^{*}$ \\
\hline & 37.63 & 33.97 & 41.91 & - & - & - & 86.61 & 74.37 & 102.15 & $0.90 *$ \\
\hline \multirow{2}{*}{ BR01-18437 x BRS 232} & 48.14 & 44.30 & 52.50 & -0.25 & -0.23 & -0.27 & 80.96 & 69.11 & 96.14 & $0.87^{*}$ \\
\hline & 47.99 & 43.71 & 52.94 & - & - & - & 80.94 & 69.55 & 95.39 & $0.87^{*}$ \\
\hline \multirow{2}{*}{ BR01-18437 x Embrapa 48} & 32.58 & 30.14 & 35.33 & 3.01 & 2.75 & 3.30 & 92.07 & 78.90 & 108.84 & $0.91^{*}$ \\
\hline & 34.31 & 31.09 & 38.05 & - & - & - & 92.34 & 79.84 & 108.02 & $0.91 *$ \\
\hline \multirow{2}{*}{ BRS 184 x BRS 231} & 23.77 & 21.90 & 25.90 & -7.12 & -6.52 & -7.81 & 97.73 & 82.98 & 116.80 & $0.92 *$ \\
\hline & 19.84 & 17.76 & 22.32 & - & - & - & 96.85 & 83.29 & 114.05 & $0.92 *$ \\
\hline \multirow{2}{*}{ BRS 184 x BRS 232} & 30.67 & 28.33 & 33.33 & 4.65 & 4.28 & 5.08 & 91.40 & 77.90 & 108.76 & $0.93 *$ \\
\hline & 33.38 & 30.11 & 37.23 & - & - & - & 91.87 & 79.11 & 108.00 & $0.93 *$ \\
\hline \multirow{2}{*}{ BRS 184 x Embrapa 48} & 17.36 & 16.07 & 18.81 & 2.44 & 2.23 & 2.68 & 102.22 & 87.47 & 121.06 & $0.92 *$ \\
\hline & 18.68 & 16.80 & 20.90 & - & - & - & 102.52 & 88.81 & 119.70 & $0.92 *$ \\
\hline \multirow{2}{*}{ BRS 231 x BRS 232} & 23.43 & 21.66 & 25.42 & 15.80 & 14.45 & 17.35 & 94.76 & 80.68 & 112.91 & $0.94 *$ \\
\hline & 32.42 & 29.20 & 36.22 & - & - & - & 96.39 & 82.92 & 113.44 & $0.93 *$ \\
\hline \multirow{2}{*}{ BRS 231 x Embrapa 48} & 37.60 & 34.72 & 40.87 & -13.95 & -12.77 & -15.32 & 105.56 & 90.24 & 125.17 & $0.92 *$ \\
\hline & 29.74 & 26.83 & 33.16 & - & - & - & 104.14 & 89.93 & 122.02 & $0.92 *$ \\
\hline \multirow{2}{*}{ BRS 232 x Embrapa 48} & 20.92 & 19.39 & 22.65 & 1.24 & 1.14 & 1.35 & 99.39 & 85.24 & 117.40 & $0.92 *$ \\
\hline & 21.60 & 19.48 & 24.10 & - & - & - & 99.54 & 86.36 & 116.00 & $0.92 *$ \\
\hline
\end{tabular}

${ }^{(1)} \sigma_{\mathrm{A}}^{2}$, additive genetic variance; $\sigma_{\mathrm{D}}^{2}$, dominance genetic variance; $\sigma_{\mathrm{E}}^{2}$, environmental variance; $\mathrm{R}^{2}$, coefficient of determination. $*$ Significant at $5 \%$ probability by the t test of Student. 
$\sigma_{\mathrm{D}}^{2}$, unless the diallel frequencies were extreme or there was overdominance (Bernardo, 2002).

Although $\sigma^{2}{ }_{D}$ is small by definition, evidences indicate that there were no loci with dominant allele interaction in the expression of resistance. These results are coherent with the greater relative contribution of the general combining ability than the specific combining ability for disease severity estimated in the same populations used by Ribeiro et al. (2009). There are also reports in the literature of the predominance of the additive effects on the genetic control of resistance to soybean Asian rust (Pierozzi, 2007; Ribeiro et al., 2007).

It is also important to emphasize the high magnitudes of the $\sigma_{\mathrm{E}}^{2}$ found. The environmental effects mask the genetic merit of the individual, and the larger the portion of the variability resulting from environmental effects in relation to the total variability, the greater the effort that should be spent for the selection of superior genotypes (Borém, 1998).

There are many options to choose from segregant populations. One of them is the estimation of heritability. The estimates of the narrow-sense heritability $\left(h_{r}^{2}\right)$ (Table 3) obtained at the $\mathrm{F}_{3}$ level ranged from 23.12 to $55.83 \%$, and were close to those reported by Pierozzi (2007) for $F_{2}$ populations. These estimates showed that successful selection is possible in the early generations of a breeding program. As the $\left(\mathrm{h}_{\mathrm{r}}^{2}\right)$ was not very high, breeders should use low-intensity selection in the first generations, so that in later generations the truly superior individuals or progenies can be identified. In this case, BR01-18437 x BRS 232 populations showed the highest heritability coefficients, which indicates that a promising progeny for resistance to soybean Asian rust can be expected. Importantly, many practical decisions are made according to the magnitude of heritability, as a direct use value of heritability in the narrow sense is to provide a subsidy for the definition of selection strategies (Ramalho et al., 1993).

Another selection strategy is the estimation of $m+a^{\prime}$, that is, the estimation of the means of the lines in the $\mathrm{F}_{\infty}$ generation that assess the potential of the populations segregating for homozygous loci sets. Thus, populations with a high estimate of $m+a^{\prime}$ have high occurrence of loci with favorable homozygous alleles (Oliveira et al., 1996) in relation to others. The values obtained for the ten populations are shown in Table 3. In this case, the ideal population would have the lowest $\mathrm{m}+\mathrm{a}^{\prime}$ estimate, that is, the $\mathrm{n}$ lines in the $\mathrm{F}_{\infty}$ generation will have low disease severity on average. The BR01-18437 x BRS 232 population was outstanding with the lowest $\mathrm{m}+\mathrm{a}$ '. The population that will generate the most susceptible lines to the pathogen (greater $\mathrm{m}+\mathrm{a}$ ' estimates) was BRS 184 x BRS 232.

Breeders need to identify the populations that present not only the best means for the trait, but also the greatest possible variation. Thus, association of $\mathrm{m}+\mathrm{a}$ ' with the $\left(h_{r}^{2}\right)$ estimate permitted the identification of populations with more chances of originating lines that meet the objectives of the breeder. Among the ten populations assessed, BR01-18437 x BRS 232 was again the best, associating the best mean in the $\mathrm{F}_{\infty}$ generation and the greatest $\left(\mathrm{h}_{\mathrm{r}}^{2}\right)$ estimate (Table 3 ).

In the situation described above, the decision depended on the estimate of two parameters $\left(m+a^{\prime}\right.$ and $\mathrm{h}_{\mathrm{r}}^{2}$ ). However, a population may not always be identified by the two favorable estimates. When this occurs, the decision can be taken using the method proposed by Jinks \& Pooni (1976), which estimates the probability of obtaining, in the $\mathrm{F}_{\infty}$ generation, lines superior to a determined standard. This method is very simple and reliable, and several authors confirmed its efficiency for some soybean characters (Toledo,

Table 3. Estimates of heritability in the narrow sense $h_{r}^{2}, m+a^{\prime}$, genetic potential and expected mean $\left(\mu_{\mathrm{F}}\right)$ of $10 \%$ of the individuals selected regarding the assessments of the percentage of leaf area infected by the Asian soybean rust. Data obtained from the assessments of the parents and the $F_{2}$ and $F_{3}$ populations at 30 and 37 days after detecting the disease, during the 2006/2007 and 2007/2008 growing seasons.

\begin{tabular}{|c|c|c|c|c|}
\hline Population & $\mathrm{h}_{\mathrm{r}}^{2}$ & $\mathrm{~m}+\mathrm{a}^{\prime}$ & Genetic potential (\%) & $\mu \mathrm{F}$ \\
\hline BR01-18437 x BRS 184 & $41.05 \pm 0.09$ & 46.09 & 9.01 & 36.93 \\
\hline BR01-18437 x BRS 231 & $45.43 \pm 0.08$ & 41.12 & 18.67 & 30.71 \\
\hline BR01-18437 x BRS 232 & $55.83 \pm 0.04$ & 39.30 & 23.89 & 26.60 \\
\hline BR01-18437 x Embrapa 48 & $40.63 \pm 0.11$ & 42.16 & 16.60 & 32.64 \\
\hline BRS 184 x BRS 231 & $25.51 \pm 0.51$ & 48.93 & 5.05 & 42.95 \\
\hline BRS 184 x BRS 232 & $39.98 \pm 0.12$ & 49.31 & 6.06 & 39.99 \\
\hline BRS 184 x Embrapa 48 & $23.12 \pm 0.77$ & 47.94 & 6.30 & 42.38 \\
\hline BRS $231 \times$ BRS 232 & $37.76 \pm 0.15$ & 46.51 & 9.34 & 37.53 \\
\hline BRS 231 x Embrapa 48 & $33.32 \pm 0.26$ & 46.27 & 9.85 & 38.09 \\
\hline BRS 232 x Embrapa 48 & $26.75 \pm 0.44$ & 47.35 & 7.08 & 40.98 \\
\hline
\end{tabular}


1987, 1989; Oliveira, 1994; Triller \& Toledo, 1996; Pierozzi, 2007; Ribeiro et al., 2007). To test the reported results, this probability was estimated using as reference the mean of the BR01-18437 parent, the most resistant among the parents assessed, minus one standard deviation. The estimates obtained confirmed that the BR01-18437 x BRS 232 population was the most likely to produce inbred lines more resistant to rust than the standard. If the BRS 184 x BRS 231 population were used for inbred line extraction, the proportion of inbred lines less affected by rust than the standard would be 4.7 times lower than the best population already mentioned (Table 3 ).

Another option for population selection, denominated "usefulness criterion", was presented by Bernardo (2002), who estimated the means of the lines selected in the $\mathrm{F}_{\infty}$ generation from information on the genetic and phenotypic components obtained in early generations $\left(\mu_{\mathrm{F}}\right)$. This estimate was also based on the fact that smaller disease estimates are better, that is, indicate greater resistance. It is perceived that there can be success with the selection of individuals with lowest severities of rust, as the predicted average is less than that observed in the field. The population derived from the cross between BR01-18437 x BRS 232 again confirmed that it would be the population in which more resistant lines could be obtained among the ten studied (Table 3). Publications on this selection strategy are scarce, but this work shows that their use can be as effective as the other three strategies tested in the study, indicating its use is important in the selection of superior populations.

\section{Conclusions}

1. Additive variance predominates in the genetic control of resistance to soybean Asian rust, and the years and time of assessment do not influence the relative estimates of the genetic parameters obtained.

2. All the procedures used for soybean population selection presented similar results and identified the BR01-18437 x BRS 232 population as the most promising for extraction of lines with resistance to Phakopsora pachyrhizi.

\section{Acknowledgments}

To Fundação de Amparo à Pesquisa do Estado de Minas Gerais, to Conselho Nacional de
Desenvolvimento Científico e Tecnológico and to Financiadora de Estudos e Projetos, for financial support.

\section{References}

BAENZIGER, P.S.; PETERSON, C.J. Genetic variation: its origin and use for breeding self-pollinated species. In: STALKER, H.T.; MURPHY, J.P. (Ed.). Plant breeding in the 1900's. North Carolina: North Carolina State University, 1991. p.69-100.

BERNARDO, R. Breeding for quantitative traits in plants. Minnesota: University of Minnesota, 2002. 368p.

BORÉM, A. Melhoramento de plantas. 2.ed. Viçosa: UFV, 1998. $453 \mathrm{p}$.

CANTERI, M.G.; GODOY, C.V. Escala diagramática para avaliação da ferrugem da soja. Summa Phytopathologica, v.29, p.89, 2003.

DEL PONTE, E.M.; GODOY, C.V.; LI, X.; YANG, X.B. Predicting severity of Asian soybean rust epidemics with empirical rainfall models. Phytopathology, v.96, p.797-803, 2006.

GARCIA, A.; CALVO, E.S.; KIIHL, R.A. de S.; HARADA, A.; HIROMOTO, D.M.; VIEIRA, L.G.E. Molecular mapping of soybean rust (Phakopsora pachyrhizi) resistance genes: discovery of a novel locus and alleles. Theoretical and Applied Genetics, v.117, p.545-553, 2008.

GODOY, C.V.; HENNING, A.A. Tratamento de semente e aplicação foliar de fungicidas para o controle da ferrugem-da-soja. Pesquisa Agropecuária Brasileira, v.43, p.1297-1302, 2008.

JINKS, J.L.; POONI, H.S. Predicting the properties of recombinant inbred lines derived by single seed descent. Heredity, v.36, p.243-246, 1976.

KOGA, L.J.; CANTERI, M.G.; CALVO, E.S.; UNFRIED, J.R.; GARCIA, A.; HARADA, A.; KIIHL, R.A. de S. Análise multivariada dos componentes da resistência à ferrugem-asiática em genótipos de soja. Pesquisa Agropecuária Brasileira, v.43, p.1277-1286, 2008.

OLIVEIRA, L.B.; RAMALHO, M.A.P.; ABREU, A. de F.B.; FERREIRA, D.F. Alternative procedures for parent choice in a breeding program for the common bean (Phaseolus vulgaris L.). Brazilian Journal of Genetics, v.19, p.611-615, 1996.

OLIVEIRA, M.F. de. Análise e previsão do potencial genético de um cruzamento de soja usando vários delineamentos em três épocas de semeadura. 1994. 114p. Dissertação (Mestrado) Universidade Estadual de Londrina, Londrina.

PIEROZZI, P.H.B. Controle genético da resistência da soja à ferrugem asiática: avaliações de severidade em campo experimental. 2007. 142p. Dissertação (Mestrado) - Universidade Estadual de Londrina, Londrina.

PIEROZZI, P.H.B.; RIBEIRO, A.S.; MOREIRA, J.U.V.; LAPERUTA, L. di C.; RACHID, B. F.; LIMA, W.F.; ARIAS, C.A.A.; OLIVEIRA, M.F. de; TOLEDO, J.F.F. de. New soybean (Glycine max Fabales, Fabaceae) sources of qualitative genetic resistance to Asian soybean rust caused by Phakopsora pachyrhizi 
(Uredinales, Phakopsoraceae). Genetics and Molecular Biology, v.31, p.505-511, 2008.

RAMALHO, M.A.P.; SANTOS, J.B. dos; ZIMMERMANN, M.J. de O. Genética quantitativa em plantas autógamas: aplicações ao melhoramento do feijoeiro. Goiânia: UFG, 1993. 271p.

RIBEIRO, A.S.; MOREIRA, J.U.V.; PIEROZZI, P.H.B.; RACHID, B.F.; TOLEDO, J.F.F. de; ARIAS, C.A.A.; SOARES, R.M.; GODOY, C.V. Genetic control of Asian rust in soybean. Euphytica, v.157, p.15-25, 2007.

RIBEIRO, A.S.; TOLEDO, J.F.F. de; ARIAS, C.A.A.; GODOY, C.V.; SOARES, R.M.; MOREIRA, J.U.V.; PIEROZZI, P.H.B.; GONÇALVES-VIDIGAL, M.C.; OLIVEIRA, M.F. de. Genetic control of soybean (Glycine max) yield in the absence and presence of the Asian rust fungus (Phakopsora pachyrhizi). Genetics and Molecular Biology, v.31, p.98-105, 2008.

RIBEIRO, A.S.; TOLEDO, J.F.F. de; RAMALHO, M.A.P. Interference of genotypes $\mathrm{x}$ environments interaction in the genetic control of resistance to Asian rust soybean. Pesquisa Agropecuária Brasileira, v.44, p.1160-1167, 2009.
SOUZA JUNIOR, C.L. de. Componentes da variância genética e suas implicações no melhoramento vegetal. Piracicaba: FEALQ, 1989. 134p.

TECNOLOGIAS de produção de soja - Paraná 2007. Londrina: Embrapa Soja, 2006. 217p. (Embrapa Soja. Sistemas de Produção, 10).

TOLEDO, J.F.F. de. Predicting the inbreeding and the outcrossing potential of soybean [Glycine $\max$ (L.) Merrill] varieties. Brazilian Journal of Genetics, v.10, p.543-558, 1987.

TOLEDO J.F.F. de. Quantitative genetics in soybean breeding. In: WORLD SOYBEAN RESEARCH CONFERENCE, 4., 1989, Buenos Aires. Proceedings. Buenos Aires: AASoja, 1989. p.909-914.

TRILLER, C.; TOLEDO, J.F.F. de. Using the $F_{3}$ generation for predicting the breeding potential of soybean crosses. Brazilian Journal of Genetics, v.19, p.289-294, 1996.

VELLO, N.A.; VENCOVSKY, R. Erros associados às estimativas de variâncias e coeficientes de herdabilidades: relatório científico do Instituto de Genética. Piracicaba: ESALQ, 1974. p.238-348.

$\overline{\text { Received on July 13, } 2009 \text { and accepted on October 29, } 2009}$ 